\title{
The Effect of Plants on the Energy Output of Green Roof Photovoltaic Systems in Tropical Climates
}

\author{
Chila Kaewpraek ${ }^{1}$, Liaqat Ali ${ }^{2}$, Md. Arefin Rahman ${ }^{3}$, Mohammad Shakeri ${ }^{4} \oplus$, M. S. Chowdhury ${ }^{1,2,5}$, \\ M. S. Jamal ${ }^{6}$, Md. Shahin Mia ${ }^{7}$, Jagadeesh Pasupuleti ${ }^{4}$, Le Khac Dong ${ }^{1}$ and Kuaanan Techato ${ }^{1,2, *(1)}$
}

check for updates

Citation: Kaewpraek, C.; Ali, L.; Rahman, M..A.; Shakeri, M.; Chowdhury, M.S.; Jamal, M.S.; Mia, M..S.; Pasupuleti, J.; Dong, L.K.; Techato, K. The Effect of Plants on the Energy Output of Green Roof Photovoltaic Systems in Tropical Climates. Sustainability 2021, 13, 4505 https://doi.org/10.3390/su13084505

Academic Editor:

Amir Ebrahimi-Moghadam

Received: 15 February 2021

Accepted: 14 April 2021

Published: 18 April 2021

Publisher's Note: MDPI stays neutral with regard to jurisdictional claims in published maps and institutional affiliations.

Copyright: (c) 2021 by the authors. Licensee MDPI, Basel, Switzerland. This article is an open access article distributed under the terms and conditions of the Creative Commons Attribution (CC BY) license (https:// creativecommons.org/licenses/by/ $4.0 /)$.

1 Faculty of Environmental Management, Prince of Songkla University, 15 Karnjanavanich Rd., HatYai 90110, Songkhla, Thailand; Chila.k@rmutsv.ac.th (C.K.); mdshahariar.c@psu.ac.th (M.S.C.); ledongthph@gmail.com (L.K.D.)

2 Sustainable Energy Management Program, Faculty of Environmental Management, Prince of Songkla University, HatYai 90110, Songkhla, Thailand; liaqatali.gorshani@gmail.com

3 Aquatic Science and Innovative Management Division, Faculty of Natural Resources, Prince of Songkla University, HatYai 90110, Songkhla, Thailand; Md.arefin75@gmail.com

4 Institute of Sustainable Energy, Universiti Tenaga Nasional, Jalan IKRAM-UNITEN (The National Energy University), Kajang 43000, Selangor, Malaysia; mshakeri@uniten.edu.my (M.S.); jagadeesh@uniten.edu.my (J.P.)

5 Environmental Assessment and Technology for Hazardous Waste Management Research Center, Faculty of Environmental Management, Prince of Songkla University, 15 Karnjanavanich Rd., HatYai 90110, Songkhla, Thailand

6 Institute of Fuel Research and Development, Bangladesh Council of Scientific and Industrial, Research Ministry of Science and Technology; Dhaka 1205, Bangladesh; msjdubd@gmail.com

7 School of Economic, Finance and Banking (SEFB), Universiti Utara Malaysia (UUM), Sintok 06010, Kedah, Malaysia; shahin@uum.edu.my

* Correspondence: kuaanan.t@psu.ac.th

\begin{abstract}
The rapid rise in the number of fossil fuel uses over the last few decades has increased carbon dioxide $\left(\mathrm{CO}_{2}\right)$ emissions. The purpose of implementing renewable energy solutions, such as solar, hydro, wind, biomass, and other renewable energy sources, is to mitigate global climate change worldwide. Solar energy has received more attention over the last few decades as an alternative source of energy, and it can play an essential role in the future of the energy industry. This is especially true of energy solutions that reduce land use, such as off-grid and on-grid solar rooftop technologies. This study aims to evaluate the energy conversion efficiency of photovoltaic (PV) systems in tropical environments. It also explores the effect of growing plants beneath PV panels. Two identical grid-connected PV systems-each containing five solar panels-were installed. The overall power production of each PV system was about $1.4 \mathrm{kWp}$. All the collected data were processed and analysed in the same way and by the same method. The PV systems were installed in two different environments-one with the possibility of growing the plants beneath the PV panels (PViGR module) and one with no possibility of growing the plants beneath the PV panels (PViSR module). The experiments were conducted in the Bo Yang District of Songkhla, Thailand over a 12-month period. Our findings indicate that green roof photovoltaic (GRPV) systems can produce around $2100 \mathrm{kWh}$ of electricity in comparison to the $2000 \mathrm{kWh}$ produced by other solar energy systems. Thereby, growing plants beneath PV panels increases electricity production efficiency by around $2 \%$. This difference comes from the growing of plants underneath GRPV systems. Plants do not only help to trap humidity underneath GRPV systems but also help to cool the PV panels by absorbing the temperature beneath GRPV systems. Thus, in the production of electrical energy; the system was clearly showing significant differences in the mentioned results of both PV solar systems, which are evident for great energy efficiency performances in the future.
\end{abstract}

Keywords: solar energy; photovoltaic panel; efficiency of a PV system; green roof 


\section{Introduction}

Global warming is the biggest challenge faced by all societies around the world today. To mitigate climate change, it is more important to develop sustainability for the atmosphere as well as to make it environmentally friendly, as well as sustainably using efficient energy and water resources [1]. Unfortunately, providing uninterrupted energy is both, a big and urgent challenge. As such, this increases the demand for more fossil fuelbased resources to produce energy, making climate change inevitable [2]. With regret, fossil fuel resources are probably going to be feasible in the future, due to growing environmental fears. Therefore, an alternative energy solution is urgently needed to prevent the depletion of energy resources.

Buildings contribute to global warming, as they consume the largest amount of electricity due to their use of industrial air conditioners. Historical data show that 1983 and 2012, less than 29 years apart, were the hottest years on record in the past 14,000 years [3]. According to the IPCC report, human activities caused around a $1.0^{\circ} \mathrm{C}$ increase in global temperature, compared to pre-industrial levels, with an approximate range of $0.8^{\circ} \mathrm{C}$ to $1.2{ }^{\circ} \mathrm{C}$. If this trend continues, global warming is presumably going to reach $1.5^{\circ} \mathrm{C}$ by 2052 [4]. The growth of an urban population that consumes vast quantities of food and produces large amounts of waste also contributes to a large portion of environmental pollution, due to the amounts of $\mathrm{CO}_{2}$ emitted during waste incineration [5]. However, these days, many technologies are trying to reduce additional energy consumption on a smaller scale, such as with rooftop gardens, eco-roofs, and cool roofs. Therefore, people can be part of the movement and can benefit from appropriate knowledge of making houses, offices, and buildings more energy efficient while growing plants on their roofs.

Based on roof thickness, there are two main types of green roofs, such as intensive green roofs and an extensive green roof. The extensive green roofs are less than $15 \mathrm{~cm}$ thick, while intensive green roofs have a roof thickness that is between 20 to $200 \mathrm{~cm}$. These layers also notably protect a building's surface from solar radiation [6]. Intensive green roofs are capable of supporting large-scale vegetation and shrubs due to them having several layers and greater thickness. Furthermore, extensive green roofs can only support very limited vegetation and grass due to their limited thickness and lack of sunlight. While intensive green roofs are very expensive and require more maintenance as well as an irrigation system, compared to intensive, extensive green roofs are easier to handle as they require less maintenance $[7,8]$. Depending on the method chosen to grow plants on the roof of a building, be it intensive or extensive, there are many ways to make green roofs moderate temperatures, such as rooftop gardens, brown/eco-roofs, live/cool roofs, or solar rooftops. Furthermore, green roofs efficiently provide backup energy and natural resources without hazardous or adverse consequences to the environment. Therefore, it is ideal that green technologies on building rooftops be utilized in conjunction with green plants.

A review of the literature revealed that the benefits of growing plants on green roofs can be broken down into three categories: ecosystem, economic, and community/society $[9,10]$. As previously mentioned, ecosystems can mitigate environmental impacts. For instance, they can serve as rain management systems, decrease the effects of urban heat island (UHI), filter the air, reduce noise pollution, improve and increase biodiversity, reduce the effects of electromagnetic radiation, and contribute to waste removal. The economic benefits include increasing the number of opportunities for businesses and, ergo, increasing employment opportunities; improving energy efficiency, serving as a stable water supply; increasing the strength of the rooftop; improving urban agriculture, etc. In terms of advantages to the public, green roofs can serve as a public facility; to be shared with the community at large; solely for individuals. It also enhances building facades and improves living conditions, especially in the sector of health.

One of the main drawbacks of green roofs is that they are very expensive projects and require a steady and regular water source to maintain. In addition to this, transporting heavy materials to the rooftops with a crane, as well as higher labour costs, are also big challenges. Not to mention that the added weight of the equipment increases the likelihood 
of the pillars and beams of the building deforming or cracking [11]. While green roofs may seem limiting, several other renewable energy resources also have multiple advantages, such as solar energy, wind energy, hydro energy, tidal energy, geothermal energy, and biomass energy. All of these sources of renewable energy can be utilized in residential and industrial areas [12]. As most Southeast Asian countries, such as Malaysia, Vietnam, Brunei, Singapore, Indonesia, Philippines, Cambodia, Myanmar, and Thailand, belong to tropical regions with hot and humid weather, these locations are where solution projects have been developed or are developing to reduce the energy crisis.

Of these countries, Thailand has the largest forestry and agricultural areas and is renowned for its rubber trees [13]. Energy security has long been a concern in Thailand. At present, Thailand is trying to utilise renewable resources to produce energy for use in residential areas and for industrial purposes [14]. In terms of environmental pollution, renewable energy sources are a much better option than non-renewable energy sources and produce very little environmental pollution. Furthermore, energy is being produced from multiple renewable energy sources, such as wind energy, geothermal energy, biomass energy, and solar energy, with the highest amount of electricity being produced by solar energy. In the future, the target of Thailand's electricity production from renewable energy resources will change: hydro energy $(2 \%)$, wind power $(15 \%)$, biogas $(3 \%)$, waste $(1 \%)$, biomass $(28 \%)$, and solar energy $(31 \%)$. Thailand aims to steer away from electricity production from methane $\left(\mathrm{CH}_{4}\right)$ [15]. Industrial manufacturing and residential sectors use the largest amount of electricity. Solar energy is a game-changing renewable energy, especially for countries in the hot and humid tropical region.

The objective of this study is not only to illustrate that green roofs reduced greenhouse emissions but to examine how rooftop gardens affect energy production. Therefore, the efficiency and performance of solar energy on its own as well as in conjunction with a rooftop garden were studied. Both systems; a regular photovoltaic PV system and a green roof photovoltaic (GRPV) system; were observed to determine if they can first support energy consumption before the difference in electricity output was determined.

\section{Materials and Methods}

This research was performed on the roof of a two-storey residential building called Feuangfa located at $7^{\circ} 11^{\prime} 58^{\prime \prime} \mathrm{N} 100^{\circ} 36^{\prime} 1^{\prime \prime}$ E in the Rajamangala University of Technology Srivijaya, Songkhla, Thailand. Data were collected from April 2017 and presented below. The experimental method and instrumentation details are as follows.

\subsection{Green Roof Photovoltaic (GRPV) System}

The GRPV was installed on the second-floor canopy of the building. The panels were set at a 15-degree tilt. Two types of panel modules were installed on the roof: namely, PViGR and PViSR. The PViGR module faced Southeast while the PViSR module faced Southwest, as shown in Figure 1. As it can be seen in Figure 1, it is possible to plant beneath the PViGR module, as PViSR is a normal system.

\subsection{0-Watt Poly-Crystalline Solar Panels}

Suntech ${ }^{\circledR} 280$-watt polycrystalline solar panels, consisting of five panels-each capable of outputting $1400 \mathrm{Wp}$ of power-were also installed on the roof of the building. This system operated with the support of a PV grid-connected system.

\subsection{Calico Plant (Alternanthera Bettzickiana)}

Our experiments were conducted using the calico plant (Alternanthera bettzickiana), a flowering plant species [16]. The plants did not exceed $30 \mathrm{~cm}$ in height and covered the surface of the soil (Figure 2). 

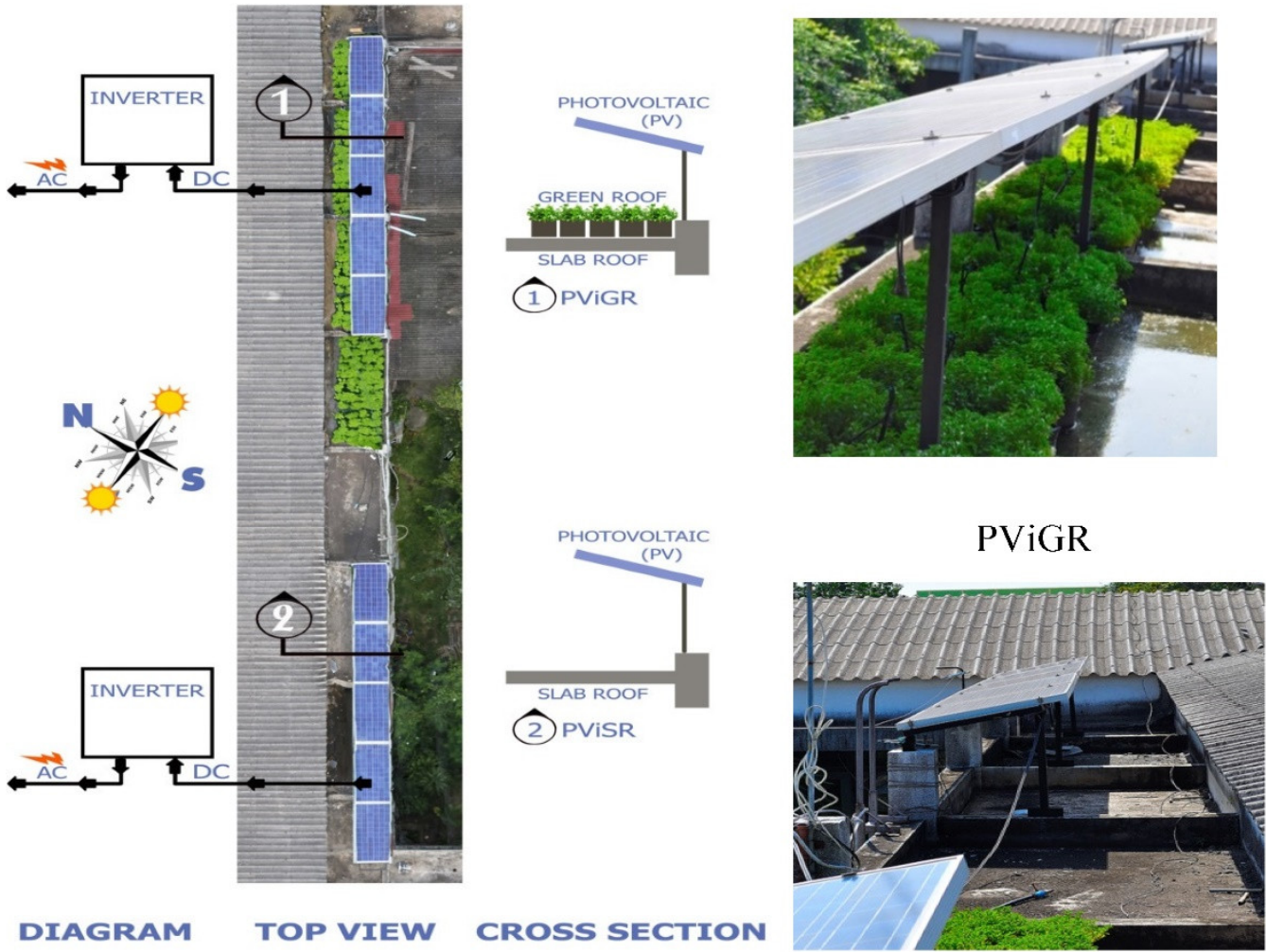

PViSR

Figure 1. PViGR and PViSR photovoltaic green roof modules.

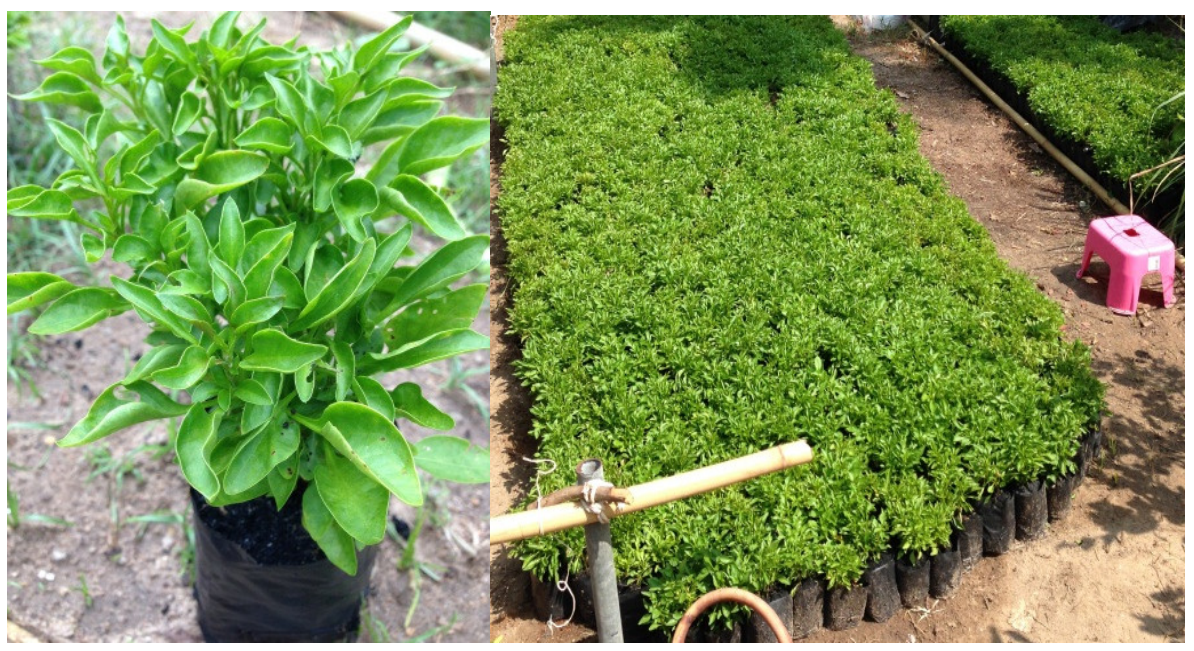

Figure 2. Calico plant (Alternanthera bettzickiana) used in the experiment.

\subsection{Data Collection}

A JFY ${ }^{\circledR}$ JSI-1500TL grid-tie inverter (Figure 3) was used to collect and transmit data wirelessly to http:/ / www.sonarman.com (15 February 2021) (Table 1). 


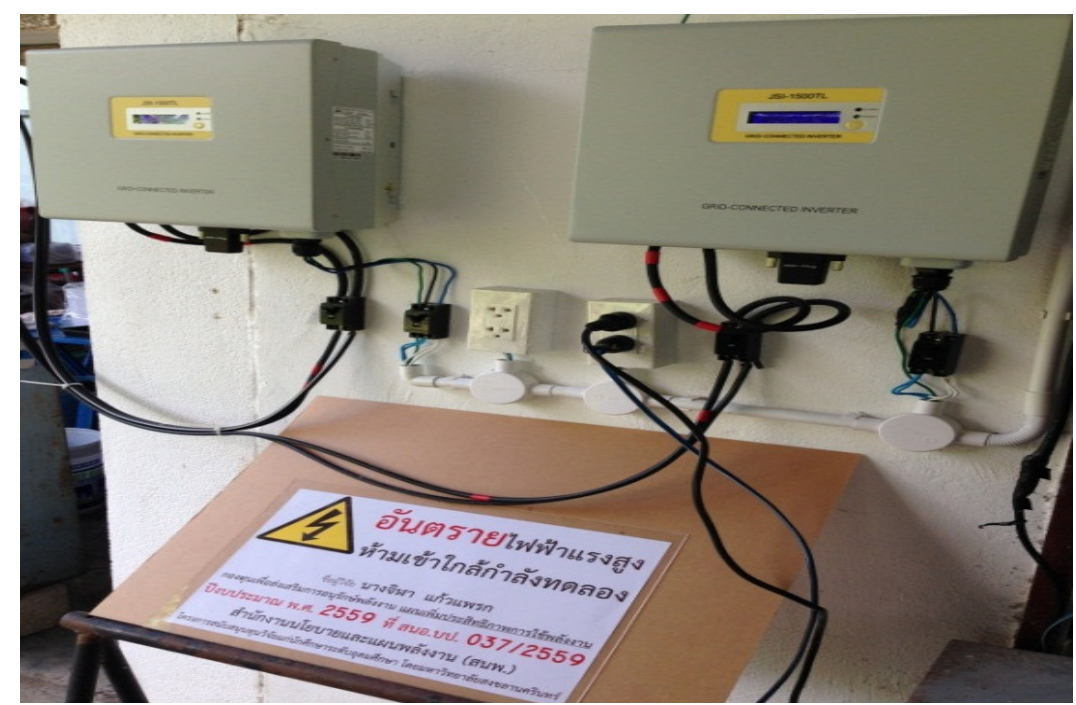

Figure 3. JFY ${ }^{\circledR}$ JSI-1500TL grid-tie inverter.

Table 1. Collected data transmitted to the website.

\begin{tabular}{cccccccc}
\hline Site Name & Country/State & City & Address & System Size & Power Now & Today's Energy & Total Energy \\
\hline PViGR_Chila & Thailand & Songkhla & $\begin{array}{c}\text { Rajamangala University of } \\
\text { Technology Srivijaya }\end{array}$ & $1.425 \mathrm{kWp}$ & $0.677 \mathrm{~kW}$ & $4.40 \mathrm{kWh}$ & $2.19 \mathrm{MWh}$ \\
\hline PSiSR_Chila & Thailand & Songkhla & $\begin{array}{c}\text { Rajamangala University of } \\
\text { Technology Srivijaya }\end{array}$ & $1.425 \mathrm{kWp}$ & $0.745 \mathrm{~kW}$ & $4.48 \mathrm{kWh}$ & $2.18 \mathrm{MWh}$ \\
\hline
\end{tabular}

\section{Results}

The PViSR and PViGR stereovision measurements were made between September 2017 and April 2018 for the purpose of verifying the effects of changes made to the design and efficiency of the PViSR, which was used to collect the data from March 2018 to April 2018 to assess design and effectiveness enhancements. As the results clearly show, PViGR had lower temperature readings on the dates of interest compared to PViSR. These two graphs reflect the findings from Songkhla Province, Thailand; Figures 4 and 5 display the average temperature and humidity over time and on the ground.

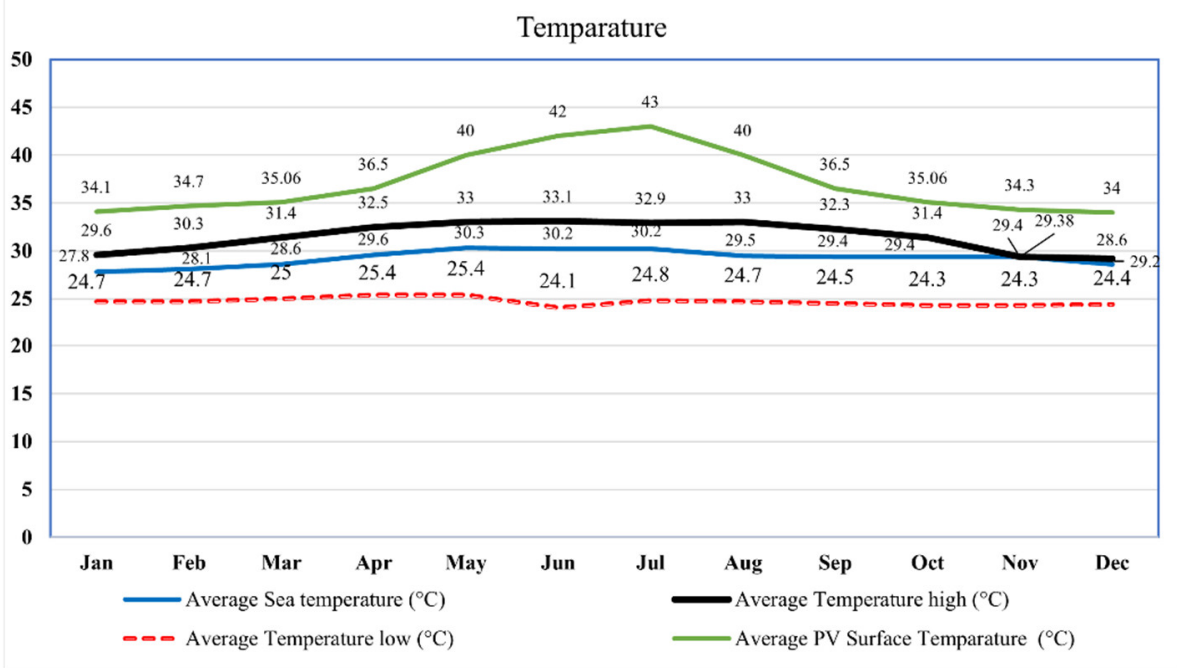

Figure 4. The variations in the difference between the average temperature in Songkhla province in Thailand. 


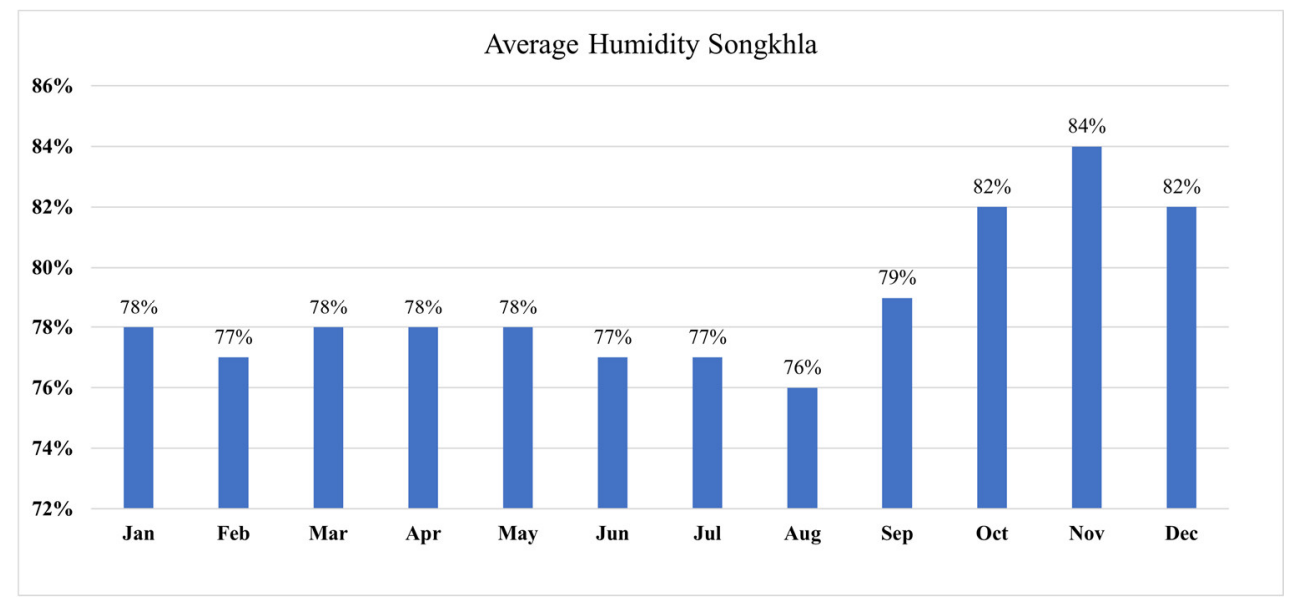

Figure 5. The average humidity in Songkhla provinces in Thailand.

Analysing the average surface PV temperatures over January and December, we can see that the surface temperature is higher between May and August, although the atmosphere and the surface temperature are only slightly higher. In contrast, Songkhla has lower humidity over the rest of the year compared to the summer months of September to December. During the early morning hours, the panel's temperature is smaller than the air temperature, since the solar cells are enclosed in low-temperature glass and aluminium products. When it is midday, the PV module's temperature rises quickly, compared to the optimal condition, which is the inverse (relationship) of the output voltage (and resultant heat).

Data were collected over a 12-month period, from between June 2017 to May 2018 (Figure 6). The same data are also shown in Table 2. The total electricity output of the PViGR module was $2106.15 \mathrm{kWh}$, with the highest output of $233.88 \mathrm{kWh}$ in March and the lowest output of $122.11 \mathrm{kWh}$ in November. The total electricity output of the PViSR module was $2065.38 \mathrm{kWh}$, with the highest output of $227.07 \mathrm{kWh}$ being in March and the lowest output of $120.22 \mathrm{kWh}$ being in November. Based on these findings, the PViGR module produced $40.77 \mathrm{kWh}$ or $1.97 \%$ more electricity than the PViSR module over 12 months.

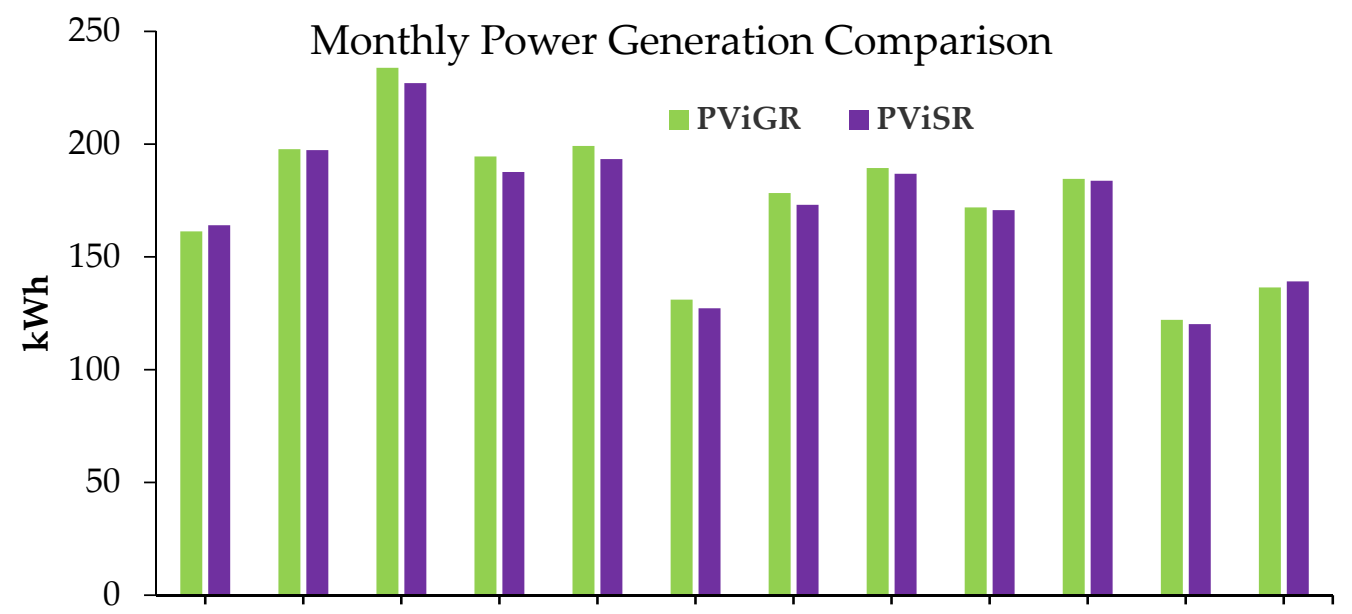

JAN. FEB. MAR. APR. MAY JUN. JUL. AUG. SEP. OCT. NOV. DEC. Months

Figure 6. Comparison of electricity output of PViGR and PViSR modules between May 2017 and April 2018. 
Table 2. Power output of PV panels (kWh).

\begin{tabular}{|c|c|c|c|c|c|c|}
\hline \multirow[t]{2}{*}{ No. } & \multirow[t]{2}{*}{ Month } & \multirow[t]{2}{*}{ Year } & \multicolumn{2}{|c|}{$\begin{array}{l}\text { The Power Output of PV Panels } \\
\text { (kWh) }\end{array}$} & \multirow[t]{2}{*}{$\begin{array}{l}\text { Different } \\
(\mathbf{k W h})\end{array}$} & \multirow[t]{2}{*}{$\begin{array}{l}\text { Percentage of } \\
\text { Different }\end{array}$} \\
\hline & & & PViGR & PViSR & & \\
\hline 1 & January & 2018 & 164.07 & 161.35 & 2.72 & 1.69 \\
\hline 2 & February & 2018 & 197.78 & 197.38 & 0.40 & 0.20 \\
\hline 3 & March & 2018 & 233.88 & 227.07 & 6.81 & 3.00 \\
\hline 4 & April & 2018 & 194.56 & 187.68 & 6.88 & 3.67 \\
\hline 5 & May & 2018 & 199.20 & 193.40 & 5.80 & 3.00 \\
\hline 6 & June & 2017 & 131.08 & 127.26 & 3.82 & 3.00 \\
\hline 7 & July & 2017 & 178.32 & 173.13 & 5.19 & 3.00 \\
\hline 8 & August & 2017 & 189.42 & 186.88 & 2.54 & 1.36 \\
\hline 9 & September & 2017 & 171.96 & 170.76 & 1.20 & 0.70 \\
\hline 10 & October & 2017 & 184.63 & 183.78 & 0.85 & 0.46 \\
\hline 11 & November & 2017 & 122.11 & 120.22 & 1.89 & 1.57 \\
\hline \multirow[t]{2}{*}{12} & December & 2017 & 139.14 & 136.47 & 2.67 & 1.96 \\
\hline & Total & & 2106.15 & 2065.38 & 40.77 & 1.97 \\
\hline
\end{tabular}

\section{Discussion}

In this section, the significant energy production results of the roof-mounted PV solar panels are explained and discussed. The obtained results are discussed in relation to the city level and economical concerns.

Energy saving is achieved by installing a photovoltaic roofing device over the top of the roof, which helps to insulate the roof surface and thereby reduce the soil temperature; this lowers the internal temperature in the building. If an increase in the amount of energy generation can be credited with any savings made, a solar PV-roofed building can balance out the section of green roof on the structure that is under development on the roof. The PV-Green Roofing System is also a viable option for high-density areas with sufficient roof space. Due to the PV system's connection to the green roof's geometry, various plant alternatives can be considered and the best ones to cool the green roof chosen, which in turn decreases the surface temperature of the PV system.

Green roofs and PV systems perform better when they are used in tandem-in a synergy - if one chooses to optimise solar energy performance. However, on the other hand, Table 2 it showed that PViGR produce more energy than PViSR. This is a promising form of renewable energy because of its many benefits, including reduced $\mathrm{CO}_{2}$ emissions, energy, the processing of both of food and fuel, and an improved environment in urban areas. Depending about how hot the PV surfaces get, they can suffer a decrease in output or see an improvement in their capacity to endure the demands of survival.

\section{Energy Production at Unit Scale}

The output of solar panels in the tropical climate in this case study was divided into four seasons over the 12 months according to the changes in the direction of sunlight over the year as it affects the device when it is installed and fixed in a certain position. The outputs of the PV panels during these four seasons are shown in Figure 7 and Table 3. From December to February, the PViGR module generated a total of $500.99 \mathrm{kWh}$ while the PViSR module produced $495.20 \mathrm{kWh}$. (1) Both modules had a total combined output of 996.19 $\mathrm{kWh}$, which was $23.88 \%$ of the total output for the year. From March to May, the PViGR module generated a total of $627.64 \mathrm{kWh}$, while the PViSR module produced $608.15 \mathrm{kWh}$. (2) Both modules had a total combined output of $1235.79 \mathrm{kWh}$, which was $29.62 \%$ of the total output for the year. From June to August, the PViGR module generated a total of $498.82 \mathrm{kWh}$, while the PViSR module produced $487.27 \mathrm{kWh}$. (3) Both modules had a total combined output of $986.09 \mathrm{kWh}$, which was $23.64 \%$ of the total output for the year. From September to November, the PViGR module generated a total of $478.70 \mathrm{kWh}$, while the PViSR module produced $474.76 \mathrm{kWh}$. (4) Both modules had a total combined output of $953.46 \mathrm{kWh}$, which was $22.86 \%$ of the total output for the year. However, plant watering conditions and the gardening activities schedule should be elaborated upon as any water that comes into contact with the surface of the PV panels will have had a cooling effect. 


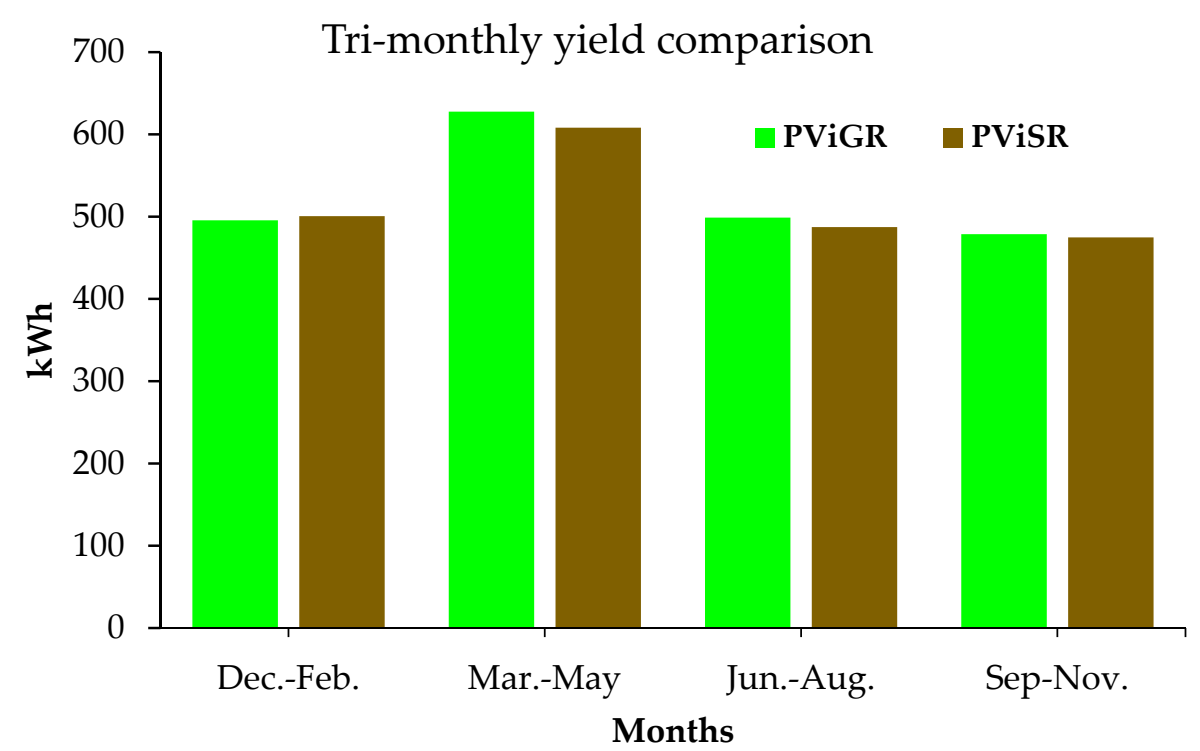

Figure 7. Comparison of PViGR and PViSR module yields every three months.

Table 3. Power output of PV panels (kWh).

\begin{tabular}{cccccc}
\hline \multirow{2}{*}{ Periods } & \multirow{2}{*}{ Months } & \multicolumn{2}{c}{ Power Output of PVpanels (kWh) } & \multirow{2}{*}{ Total (kWh) } & \multirow{2}{*}{ Percentage } \\
\cline { 3 - 4 } & & PViGR & PViSR & & \\
\hline 1 & Dec-Feb & 500.99 & 495.20 & 996.19 & 23.88 \\
2 & Mar-May & 627.64 & 08.15 & 1235.79 & 29.64 \\
3 & Jun-Aug & 498.82 & 487.27 & 986.09 & 23.64 \\
4 & Sep-Nov & 478.70 & 474.76 & 953.46 & 22.86 \\
\hline
\end{tabular}

The significant results of the PV panels were discussed based on their performance and innovation. The results of this study were compared with the results of other previous studies to determine the efficiency of our GRPV system.

The $500.99 \mathrm{kWh}$ generated by the PViGR module and the $495.20 \mathrm{kWh}$ generated by the PViSR module between December to February were higher than that of the electricity generated by a QIoad ${ }^{\circledR}$ single-storage tank solar domestic water heater in January (211.111 kWh), February (211.111 kWh), and December (211.111 kWh) [17]. The results of the Harrabi et al. (2021) were converted from MJ to kWh for comparison purposes. Son and Jung [18] reported that a PV panel installation is the most efficient and in-demand electricity generation system, as it costs less and is smaller than other renewable energy sources $[19,20]$. Moreover, PV units are more easily expanded from one region to other regions and they are also easier to handle. Therefore, PV panels that are equipped with the best system and are able to produce the best performance have the highest chance of mitigating the energy crises of the future.

\section{Conclusions}

This study compared two modules to determine the efficacy of solar panels in a tropical climate. Temperature, humidity, sunlight, wind, and rainwater are important variables that have a big impact on the atmosphere and are out of our control in reallife environments. Our results indicate that green roofs positively affect the temperature beneath solar panels and improve solar energy efficiency. The results were collected from two modules: a PViGR module and a PViSR module. From December to February, the PViGR module generated a total of $500.99 \mathrm{kWh}$, while the PViSR module generated a total of $495.20 \mathrm{kWh}$. These results indicate that both modules are highly capable of producing clean energy. However, the PViGR module was the more efficient module of the two. As these modules produced significant amounts of energy at the lowest cost, it may provide 
a solution to energy crises in the future. Based on our findings, PV systems are not only effective at improving the thermal performance of buildings but GRPV systems with proper vegetation are also effective at improving and managing heatwaves. Therefore, more of these types of cost-effective projects should be introduced in the future as they save the environment and also help alleviate the energy crisis.

Author Contributions: Conceptualization, C.K.; methodology, C.K.; software, L.A.; validation, M.S.C., M.S.J. and M.S.; formal analysis, L.A. and M.S.; investigation, J.P. and M.S.M.; resources, L.K.D., M.S.M. and M.S.J.; data curation, L.K.D., M.S. and J.P.; writing-original draft preparation, C.K.; writing-review and editing, M.A.R., C.K. and M.S.C.; visualization, M.A.R. and M.S.J.; supervision, K.T.; project administration, K.T.; funding acquisition, K.T. All authors have read and agreed to the published version of the manuscript.

Funding: Not Applicable.

Institutional Review Board Statement: Not Applicable.

Informed Consent Statement: Not Applicable.

Data Availability Statement: Not Applicable.

Acknowledgments: The authors would like to thank the Research and Development Office (RDO), Prince of Songkla University, Thailand, through to ENV6402012N.

Conflicts of Interest: The authors declare no conflict of interest.

\section{References}

1. Maftouni, N.; Khodami, S.S. Climate comparative building energy optimization: A retrofit approach including solar photovoltaic panels and natural ventilation. J. Sol. Energy Res. 1999, 5, 314-331.

2. Al Asbahi, A.A.M.H.; Fang, Z.; Chandio, Z.A.; Tunio, M.K.; Ahmed, J.; Abbas, M. Assessing barriers and solutions for Yemen energy crisis to adopt green and sustainable practices: A fuzzy multi-criteria analysis. Environ. Sci. Pollut. Res. 2020, 27, 36765-36781. [CrossRef] [PubMed]

3. Isaac, M.; van Vuuren, D.P. Modeling global residential sector energy demand for heating and air conditioning in the context of climate change. Energy Policy 2009, 37, 507-521. [CrossRef]

4. IPCC. Summary for Policymakers. In Global Warming Of $1.5^{\circ} \mathrm{C}$. An IPCC Special Report on the Impacts of Global Warming Of $1.5^{\circ} \mathrm{C}$ above Pre-Industrial Levels and Related Global Greenhouse Gas Emission Pathways, in the Context of Strengthening the Global Response to the Threat of Climate Change, Sustainable Development, and Efforts to Eradicate Poverty; Masson-Delmotte, V., Zhai, P., Pörtner, H.-O., Roberts, D., Skea, J., Shukla, P.R., Pirani, A., Moufouma-Okia, W., Péan, C., Pidcock, R., et al., Eds.; World Meteorological Organization: Geneva, Switzerland, 2018; p. 32.

5. Sztubecka, M.; Skiba, M.; Mrówczyńska, M.; Bazan-Krzywoszańska, A. An Innovative Decision Support System to Improve the Energy Efficiency of Buildings in Urban Areas. Remote Sens. 2020, 12, 259. [CrossRef]

6. Morakinyo, T.E.; Dahanayake, K.; Ng, E.; Chow, C.L. Temperature and cooling demand reduction by green-roof types in different climates and urban densities: A co-simulation parametric study. Energy Build. 2017, 145, 226-237. [CrossRef]

7. Silva, C.M.; Gomes, M.G.; Silva, M. Green roofs energy performance in Mediterranean climate. Energy Build. 2016, 116, 318-325. [CrossRef]

8. Razzaghmanesh, M.; Beecham, S.; Kazemi, F. The growth and survival of plants in urban green roofs in a dry climate. Sci. Total. Environ. 2014, 476-477, 288-297. [CrossRef] [PubMed]

9. Dewan, A.; Donovan, C.; Heo, D.; Beyenal, H. Evaluating the performance of microbial fuel cells powering electronic devices. $J$. Power Sources 2010, 195, 90-96. [CrossRef]

10. Hartmann, A.; Rothballer, M.; Schmid, M. Lorenz Hiltner, a pioneer in rhizosphere microbial ecology and soil bacteriology research. Plant. Soil 2007, 312, 7-14. [CrossRef]

11. Bianchini, F.; Hewage, K. How "green" are the green roofs? Lifecycle analysis of green roof materials. Build. Environ. 2012, 48, 57-65. [CrossRef]

12. Asif, M.; Muneer, T. Energy supply, its demand and security issues for developed and emerging economies. Renew. Sustain. Energy Rev. 2007, 11, 1388-1413. [CrossRef]

13. Arifin, B. On the Competitiveness and Sustainability of the Indonesian Agricultural Export Commodities. 2013. Available online: https:/ / fem.ipb.ac.id/miicema/e-journal2/wp-content/uploads/2015/09/6.pdf (accessed on 30 March 2021).

14. Rennkamp, B.; Haunss, S.; Wongsa, K.; Ortega, A.; Casamadrid, E. Competing coalitions: The politics of renewable energy and fossil fuels in Mexico, South Africa and Thailand. Energy Res. Soc. Sci. 2017, 34, 214-223. [CrossRef]

15. Muangjai, P.; Wongsapai, W.; Bunchuaidee, R.; Tridech, N.; Damrongsak, D.; Ritkrerkkrai, C. Marginal abatement cost of electricity generation from renewable energy in Thailand. Energy Rep. 2020, 6, 767-773. [CrossRef] 
16. Kaewkannetra, P.; Chiwes, W.; Chiu, T. Treatment of cassava mill wastewater and production of electricity through microbial fuel cell technology. Fuel 2011, 90, 2746-2750. [CrossRef]

17. Harrabi, I.; Hamdi, M.; Bessifi, A.; Hazami, M. Dynamic modeling of solar thermal collectors for domestic hot water production using TRNSYS. Euro-Mediterr. J. Environ. Integr. 2021, 6, 1-17. [CrossRef]

18. Son, N.; Jung, M. Analysis of Meteorological Factor Multivariate Models for Medium- and Long-Term Photovoltaic Solar Power Forecasting Using Long Short-Term Memory. Appl. Sci. 2020, 11, 316. [CrossRef]

19. Jeon, W.; Cho, S.; Lee, S. Estimating the Impact of Electric Vehicle Demand Response Programs in a Grid with Varying Levels of Renewable Energy Sources: Time-of-Use Tariff versus Smart Charging. Energies 2020, 13, 4365. [CrossRef]

20. Sinha, A.; Shahbaz, M.; Sengupta, T. Renewable energy policies and contradictions in causality: A case of Next 11 countries. J. Clean. Prod. 2018, 197, 73-84. [CrossRef] 